\title{
GC 2012-5639: EFFECT OF WOMEN IN ENGINEERING PROGRAMS ON CAREER DEVELOPMENT OF FEMALE ENGINEERING STUDENTS
}

\author{
Dong Ik Kim, Kunsun University \\ Prof. Myongsook Susan Oh, Hongik University
}

Myongsook Oh is a professor of Chemical Engineering Department at Hongik University in Seoul. She obtained a B.S. degree in chemical engineering from the University of California at Berkeley, and Sc. D. from Massachusetts Institute of Technology (MIT). Before joining Hongik University, Dr. Oh was associated with Lawrence Livermore National Laboratory (LLNL) and Texaco, Inc in the U. S. Starting from her Sc. D. thesis on softening coal pyrolysis, she worked on the conversion of fossil fuels for over 30 years. She has continued working on the coal gasification in Korea, providing leadership in gasification slag rheology and refractory corrosion.

The other area that Dr. Oh devotes her effort is to develop women in engineering program and educational contents. With her colleagues, she introduced the concept of engineering education for women (EEW). For last seven years, she organized and chaired the EEW session in the annual conference of Korean Society of Engineering Education (KSEE).. Dr. Oh now serves as a vice president of Korea Federation of Women's Science and Technology Associations, a vice president of Korean KSEE, and a director of the Regional center for Women in Science, Engineering and Technology in Seoul.

She also served several government committees such as Energy Technology Advisory Committee and New and Renewable Energy Committee in the Ministry of Commerce, Industry and Energy, Korea. She is an active member of in ACS, KIChE, KSIEC, ASEE, and KSEE. She is a member of the National Academy of Engineering of Korea (NAEK). 


\title{
Effect of Women in Engineering Programs on the Retention of Female Engineering Students
}

\author{
Dong Ik Kim*, Young Hwa Lee* and Myongsook S. Oh**, $†$ \\ *Kunsan University, Cheonrabuk-do, Korea \\ **Hongik University, Seoul, Korea, †Speaker
}

\begin{abstract}
This study investigated the effect of Women in Engineering (WIE) Programs that were developed to improve the retention and employment rate of female students in engineering. 207 female engineering students were surveyed for psychological correlates of career development in engineering and for self-evaluation of competency in various hard and soft skills. The level of psychological correlates, occupational competency and employment rate of female engineering graduates from 2007 through 2011 were analyzed as a function of program participation. The results showed that the WIE programs not only improved the employment ratio, but also improved psychological correlates, such as self efficacy, initiative, and willingness to challenge. Female students, in general, have a high level of aspiration for engineering careers, but have a relatively low employment self efficacy. However, the group of students who participated in various WIE programs showed a higher employment self efficacy as well as a higher employment rate than the group who did not participate.
\end{abstract}

\section{Introduction}

Engineering remains the only field that has a low female ratio throughout the industrialized world. The masculine image of engineering causes difficulties in recruiting and retention of female students, regardless of scholastic achievements. Several studies showed that if the ratio of one gender is less than a critical mass of $30 \%$, there is a need for specialized programs to improve the gender ratio and the retention rate of the minority gender ${ }^{1-3}$. In western countries such as the United States, the programs for women in science and engineering started in the 1980s, and most 4-year engineering colleges have programs for recruiting and retaining female engineering students.

The ratio of women in Korean 4-year engineering colleges has been at about $18 \%$ for the last 15 years. Kim et al. ${ }^{2,3}$ investigated the psychological characteristics of almost 2000 female and male engineering students in 8 universities nation-wide, including the measures for self career aspiration, self efficacy, satisfaction and expectation in engineering careers. The results revealed that female students scored significantly lower than male students for all of these variables. It was concluded that in order to improve the retention rate, the program for women in engineering must start with improving psychological correlates of career development.

The Women in Engineering Program in Korea was started in 2006, the first of its kind in Korea that targeted female engineering students. Five universities in different regions in Korea were funded for 6 years to develop programs in 3 sub-target areas: (1) To promote an inclusive educational environment for female engineering students, (2) To develop 
specialized programs to enhance competency in various hard and soft skills and (3) To increase the employment rate in the field related to one's major. This paper introduces the WIE program developed in Kunsan University in Cheonrabuk-do and summarizes the outcome of the first 5-year programs in terms of improvements in psychological correlates, retention rate, and employment rate.

\section{Program Details}

The programs in the three sub-areas are listed in Tables 1-3. The inclusive environment programs include programs for faculty and students, as well as research programs to develop effective teaching pedagogies for female students. The competency enhancement programs have both technical and non-technical programs. Employment support programs include various training programs related to employment preparation.

Table 1. Programs to create inclusive educational environments

\begin{tabular}{|l|c|}
\hline \multicolumn{1}{|c|}{ Program } & \multicolumn{1}{c|}{ Contents } \\
\hline $\begin{array}{l}\text { Faculty } \\
\text { Workshops }\end{array}$ & $\begin{array}{c}\text { Regular meetings of engineering and non-engineering faculties to explore } \\
\text { gender issues in diverse educational activities and to develop action plans. }\end{array}$ \\
\hline $\begin{array}{l}\text { Research } \\
\text { Projects }\end{array}$ & $\begin{array}{c}\text { Research to develop inclusive pedagogies, strategies for implementation } \\
\text { and assessment methods of program outcomes. }\end{array}$ \\
\hline $\begin{array}{l}\text { Inclusive } \\
\text { Lectures }\end{array}$ & Develop lecture plans to apply inclusive pedagogies in engineering classes. \\
\hline $\begin{array}{l}\text { Student } \\
\text { Seminar }\end{array}$ & $\begin{array}{c}\text { Understanding of gender issues between male and female students to } \\
\text { improve teamwork with different genders. Organized and run by students. }\end{array}$ \\
\hline
\end{tabular}

Table 2. Programs for competency enhancement

\begin{tabular}{|l|l|}
\hline \multicolumn{1}{|c|}{ Program } & \multicolumn{1}{c|}{ Contents } \\
\hline $\begin{array}{l}\text { Hands-on } \\
\text { laboratory } \\
\text { Programs }\end{array}$ & $\begin{array}{l}\text { Hands-on laboratories, specially designed for female students to relieve } \\
\text { fears of machines and equipment and to improve confidence in their major. } \\
\text { The program provides the basic skills that are not covered in a regular } \\
\text { curriculum. Details in Table 4. }\end{array}$ \\
\hline $\begin{array}{l}\text { Certificate } \\
\text { Acquisition }\end{array}$ & $\begin{array}{l}\text { Special lectures to support students to acquire certificates in MOS, CAD, } \\
\text { Six-sigma, etc. }\end{array}$ \\
\hline $\begin{array}{l}\text { Tutoring } \\
\text { Program }\end{array}$ & $\begin{array}{l}\text { Tutoring on lower division subjects to raise confidence in engineering } \\
\text { subjects and thereby improve retention rate. }\end{array}$ \\
\hline $\begin{array}{l}\text { Student- } \\
\text { directed } \\
\text { Seminar }\end{array}$ & $\begin{array}{l}\text { A group of 2-3 students organizes a student seminar in the topic of their } \\
\text { choice. Improves student initiative and leadership. }\end{array}$ \\
\hline Plant visits & $\begin{array}{l}\text { Students are responsible for contacting industry, planning a visit, and } \\
\text { submitting a report. Work as a group of 2-3 students. Visits to a plant abroad } \\
\text { are also supported. }\end{array}$ \\
\hline
\end{tabular}




\begin{tabular}{|l|l|}
\hline $\begin{array}{l}\text { College-Life } \\
\text { Roadmap } \\
\text { Contest }\end{array}$ & Develop a detailed goal to achieve during college years. \\
\hline Mentoring & Mentoring by women engineers in the region and by female alumni \\
\hline
\end{tabular}

Table 3. Employment support programs

\begin{tabular}{|l|l|}
\hline \multicolumn{1}{|c|}{ Program } & \multicolumn{1}{c|}{ Contents } \\
\hline $\begin{array}{l}\text { Product Idea } \\
\text { Contest }\end{array}$ & $\begin{array}{l}\text { Provides opportunities to apply what has been learned and come up with } \\
\text { actual products that can be manufactured. }\end{array}$ \\
\hline Seminars & Seminars by professionals from industry \\
\hline Job Search & $\begin{array}{l}\text { Employment preparation seminar and camp on topics related to job search } \\
\text { and interviews. }\end{array}$ \\
\hline $\begin{array}{l}\text { Corporate } \\
\text { Analysis }\end{array}$ & $\begin{array}{l}\text { Seminar on corporate analysis methodology, followed by a contest on actual } \\
\text { analyses. Help student to get in-depth knowledge of the company they want } \\
\text { to work for. }\end{array}$ \\
\hline
\end{tabular}

The hands-on laboratory program for female students was initiated in 2004, even before the WIE program was funded, to provide hands-on experience on machines, equipment, and electrical devices. The program includes basic skills on machine and equipment operation, electronics, materials processing, chemical analysis, blueprints, etc. The students form a team of 2 or 3 , and select the program and the schedule. The program started as an extracurricular activity, but became a regular credit course, awarding 1 credit (equivalent of 16 lecture hours/semester) for 32 hours of program participation.

Table 6. Hands-on laboratory programs (hours required to complete the course)

\begin{tabular}{|l|l|}
\hline & \\
\hline $\begin{array}{l}\text { Machine and } \\
\text { Equipment } \\
\text { Operation }\end{array}$ & $\begin{array}{l}\text { Vacuum system operation(8), Gas piping and applications(4), Tool basics } \\
\text { (4), Plant automation(6), Piping basics(6), Electrical components wiring } \\
\text { (8), Pneumatic pressure (8) }\end{array}$ \\
\hline $\begin{array}{l}\text { Basic } \\
\text { Electronics }\end{array}$ & $\begin{array}{l}\text { Electrical wiring (8), How to use a multi-meter (4), How to use a } \\
\text { voltmeter and an ammeter (4), Electrical component identification and } \\
\text { testing (4), Diagnosis of electrical circuit problems (4), Fuses (4), PC } \\
\text { assembly (6), Digital Engineering Experiments (18) }\end{array}$ \\
\hline $\begin{array}{l}\text { Materials } \\
\text { Processing }\end{array}$ & Lathe machining (8), Mechanical Draft (12) \\
\hline $\begin{array}{l}\text { Chemical } \\
\text { Analyses }\end{array}$ & $\begin{array}{l}\text { Ammonia analysis(4), Total nitrogen analysis (4), Total phosphorous } \\
\text { analysis (4), Analysis of ammonia in air (4), Analysis of sulfur oxides (4) }\end{array}$ \\
\hline Blueprints/CAD & How to read blue prints(4), CAD I(12), CAD II(12), \\
\hline Miscellaneous & $\begin{array}{l}\text { Presentation Skills (6), Basic Automobile maintenance (6), Fuel Cells } \\
\text { (10), Excel I (10), Excel II (10), Basic Principles of Robots (6) }\end{array}$ \\
\hline
\end{tabular}




\section{Program Outcome Assessments}

In order to evaluate the program outcome, 207 female engineering students were surveyed for psychological correlates of career development in engineering, and self-evaluation of competency in various hard and soft skills, ${ }^{4,5}$. The level of psychological correlates, occupational competency and the employment rate of female engineering graduates from 2007 through 2011 were analyzed as a function of program participation, using a scale of 1 to 5. For the 11 programs that have a relatively high participation rate, the effect of each program on student self-evaluation of competency was analyzed. The level of competency was examined in 8 categories, such as confidence, academic comprehension, equipment handling, willingness to challenge, presentation skills, cooperative skills, leadership and initiative.

\section{Results}

\subsection{Psychological characteristics related to career development}

The survey of the psychological correlates of career development (desire for employment related to one's major, employment self-efficacy, career aspiration) showed that desire for employment in the field of one's major and career aspiration were above the mid-level on a 5 point scale, but the employment self-efficacy was relatively low. In terms of program participation, the group with program experience showed more positive correlates, and those with program participation of 6 times or more showed a higher score than those with 1 to 5 times of participation. The results are summarized in Table 5.

Table 5. Psychological correlates of career development as a function of program participation.

\begin{tabular}{|c|c|c|c|c|c|c|c|c|c|c|}
\hline \multirow{2}{*}{$\begin{array}{l}\text { Number of } \\
\text { Programs } \\
\text { Participated }\end{array}$} & \multirow[t]{2}{*}{$\mathrm{N}$} & \multicolumn{3}{|c|}{$\begin{array}{c}\text { Desire for } \\
\text { employment related } \\
\text { to their major }\end{array}$} & \multicolumn{3}{|c|}{$\begin{array}{c}\text { Employment self- } \\
\text { efficacy }\end{array}$} & \multicolumn{3}{|c|}{ Career aspiration } \\
\hline & & $\mathrm{M}$ & (SD) & $\mathrm{D}$ & $\mathrm{M}$ & (SD) & $\mathrm{D}$ & M & SD & $\mathrm{D}$ \\
\hline Never & 38 & 3.15 & $(.81)$ & A & 2.55 & $(.71)$ & A & 3.33 & $(1.03)$ & A \\
\hline $1-5$ times & 128 & 3.57 & $(.81)$ & $\mathrm{B}$ & 2.87 & $(.61)$ & $\mathrm{B}$ & 3.63 & $(1.02)$ & $\mathrm{AB}$ \\
\hline More than 6 times & 41 & 3.81 & $(.66)$ & $\mathrm{B}$ & 2.99 & $(.51)$ & $\mathrm{B}$ & 4.01 & $(.90)$ & $\mathrm{B}$ \\
\hline \multicolumn{2}{|l|}{$\mathrm{F}$} & \multicolumn{3}{|c|}{$7.150^{* * *}$} & \multicolumn{3}{|c|}{$5.423^{* *}$} & \multicolumn{3}{|c|}{$4.379^{* *}$} \\
\hline
\end{tabular}

${ }^{* *} \mathrm{p}<.01{ }^{* * *} \mathrm{p}<.001, \mathrm{D}:$ Duncan Multiple Range Test

\subsection{Self-evaluation of competency improvement through the WIE programs}

The results on self-evaluation of competency in various hard and soft skills showed that initiative, willingness to challenge, and confidence improved significantly and each program accomplished the program goal. The survey results are shown in Table 6. 
Table 6. Self-evaluation of competency improvement through the WIE programs

\begin{tabular}{|c|c|c|c|c|c|c|c|c|c|c|c|c|c|c|c|c|}
\hline \multirow{3}{*}{ Program } & \multicolumn{16}{|c|}{ Competency } \\
\hline & \multicolumn{2}{|c|}{ (a) } & \multicolumn{2}{|c|}{ (b) } & \multicolumn{2}{|r|}{ (c) } & \multicolumn{2}{|c|}{ (d) } & \multicolumn{2}{|c|}{ (e) } & \multicolumn{2}{|c|}{ (f) } & \multicolumn{2}{|c|}{ (g) } & \multicolumn{2}{|c|}{ (h) } \\
\hline & M & (SD) & $\mathrm{M}$ & (SD) & M & (SD) & $\mathrm{M}$ & (SD) & $\mathrm{M}$ & (SD) & $\mathrm{M}$ & $(\mathrm{SD})$ & $\mathrm{M}$ & $(\mathrm{SD})$ & $\mathrm{M}$ & $(\mathrm{SD})$ \\
\hline Tutoring & 3.11 & $(1.00)$ & 3.42 & $(1.11)$ & 2.44 & $(1.00)$ & 2.98 & $(.81)$ & 2.89 & $(1.05)$ & 3.10 & $(.97)$ & 2.73 & $(.81)$ & 3.52 & $(.97)$ \\
\hline $\begin{array}{l}\text { Student } \\
\text { seminar }\end{array}$ & 3.68 & $(1.10)$ & 3.40 & $(.91)$ & 2.50 & $(1.08)$ & 3.71 & (1.17) & 3.51 & $(.98)$ & 3.48 & $(1.03)$ & 3.54 & $(1.09)$ & 3.68 & $(1.10)$ \\
\hline $\begin{array}{l}\text { Hands-on } \\
\text { Lab }\end{array}$ & 3.88 & $(.95)$ & 3.86 & $(.92)$ & 3.76 & $(1.06)$ & 3.80 & $(.89)$ & 3.16 & $(.83)$ & 3.62 & $(.93)$ & 3.35 & $(1.02)$ & 3.71 & $(1.03)$ \\
\hline $\begin{array}{l}\text { Certificates } \\
\text { acquisition }\end{array}$ & 3.96 & $(1.05)$ & 3.87 & $(1.07)$ & 3.83 & $(1.12)$ & 3.80 & $(.89)$ & 3.49 & $(.99)$ & 3.49 & $(1.03)$ & 3.34 & $(1.09)$ & 3.71 & (1.11) \\
\hline Plant visits & 3.93 & $(1.19)$ & 3.93 & $(1.09)$ & 3.17 & (1.33) & 4.06 & (1.13) & 3.60 & $(1.22)$ & 3.71 & $(1.32)$ & 3.78 & $(1.16)$ & 3.96 & $(1.13)$ \\
\hline $\begin{array}{l}\text { Student } \\
\text { directed } \\
\text { seminar } \\
\end{array}$ & 3.91 & $(.98)$ & 3.38 & $(.73)$ & 2.63 & $(1.08)$ & 3.83 & $(.95)$ & 4.08 & $(1.04)$ & 3.62 & $(1.04)$ & 3.78 & $(1.10)$ & 3.95 & $(1.06)$ \\
\hline Plant trips & 3.53 & $(1.01)$ & 3.46 & $(1.01)$ & 2.97 & $(1.21)$ & 3.48 & $(1.01)$ & 3.06 & $(.98)$ & 3.15 & $(.96)$ & 3.22 & $(1.03)$ & 3.59 & $(.81)$ \\
\hline $\begin{array}{l}\text { Employment } \\
\text { preparation } \\
\text { camp }\end{array}$ & 3.77 & $(1.25)$ & 3.32 & (1.15) & 2.39 & $(1.10)$ & 3.89 & $(1.03)$ & 3.46 & $(.96)$ & 3.31 & $(1.10)$ & 3.51 & $(1.08)$ & 3.72 & $(.99)$ \\
\hline $\begin{array}{l}\text { Seminar/ } \\
\text { Lectures }\end{array}$ & 3.58 & $(.94)$ & 3.45 & $(.98)$ & 2.86 & $(1.14)$ & 3.49 & $(.88)$ & 3.11 & $(.82)$ & 3.09 & $(.98)$ & 3.22 & $(1.03)$ & 3.36 & $(.99)$ \\
\hline Mentoring & 3.87 & $(.87)$ & 3.68 & $(.99)$ & 2.84 & $(1.32)$ & 3.71 & $(.88)$ & 3.65 & $(.97)$ & 3.28 & $(1.17)$ & 3.43 & $(.94)$ & 4.00 & $(.84)$ \\
\hline $\begin{array}{l}\text { Designated } \\
\text { Advisors }\end{array}$ & 3.78 & $(.89)$ & 3.70 & $(.81)$ & 2.77 & $(1.10)$ & 3.48 & $(.89)$ & 3.23 & (1.04) & 3.09 & $(1.00)$ & 3.20 & $(.94)$ & 3.84 & $(.89)$ \\
\hline
\end{tabular}

(a) Confidence (b) Academic Comprehension (c) equipment handling (d) Willingness to challenge (e) Presentation skills (f) Cooperative skills (g) Leadership (h) Initiative

\subsection{Improvement in the employment ratio}

Before the WIE program was started, the employment ratio was $44.8 \%$, and only $56.4 \%$ of those employed were in a major related field. After systematic support through the WIE program, the employment ratio increased steadily, showing a total employment ratio of $78.5 \%$ in 2011 , and $86.3 \%$ of them $(67.7 \%$ of the total) were employed in a field related to their major. For the Hands-on Laboratory Program, one of the main programs of the Kunsan WIE Program, program participation was correlated with the employment ratio. The result shows that there was a statistically significant difference between the groups with and without program experience. Both employment ratio and employment related to the major were much higher for the group with program participation experience, as shown in Tables 7 and 8. 
Table 7. Effect of WIE program on employment rate of female engineering students

\begin{tabular}{|c|c|c|c|c|c|c|}
\hline & $\begin{array}{c}\text { Before } \\
\text { WIE }\end{array}$ & 2007 & 2008 & 2009 & 2010 & 2011 \\
\hline$\%$ Employment & $44.8 \%$ & $55.6 \%$ & $70.3 \%$ & $75.4 \%$ & $73.6 \%$ & $78.5 \%$ \\
\hline $\begin{array}{c}\text { \% Employment } \\
\text { related to their major }\end{array}$ & $25.3 \%$ & $36.3 \%$ & $45.3 \%$ & $50.7 \%$ & $52.8 \%$ & $67.7 \%$ \\
\hline
\end{tabular}

Table 8. Effect of hands-on lab program on employment rate of graduates from 2007 to 2011

\begin{tabular}{|c|c|c|c|c|}
\hline \multirow{2}{*}{ Employment status upon graduation } & \multicolumn{2}{|c|}{ Program Participation Experience } & \multirow{2}{*}{$\mathrm{x}^{2}$} \\
\cline { 2 - 4 } & Participated & Not participated & \\
\hline \multirow{3}{*}{ employed } & Major-related & $101(63.5 \%)$ & $28(34.1 \%)$ & \multirow{2}{*}{$18.77 * * *$} \\
\cline { 2 - 4 } & Major-unrelated & $58(36.5 \%)$ & $54(65.9 \%)$ & \\
\cline { 2 - 4 } & total & $130(81.8 \%)$ & $54(65.9 \%)$ & \multirow{2}{*}{$7.58^{* *}$} \\
\hline \multicolumn{2}{|c|}{ Unemployed } & $29(18.2 \%)$ & $28(34.1 \%)$ & \\
\hline \multicolumn{2}{|c|}{ total } & $159(100.0 \%)$ & $82(100.0 \%)$ & \\
\hline
\end{tabular}

\subsection{Effect on the retention rate}

One of the WIE program goals is to improve the retention rate of female engineering students. The retention rate of female students is compared before and after the WIE program in Table 9. The retention rate of female students after 2006 was $85.8 \%$, which is an over $10 \%$ improvement compared to the $75.7 \%$ before 2006 .

Table 9. Changes in Retention of female students before and after the WIE program

\begin{tabular}{|c|c|c|c|c|c|c|c|c|}
\hline \multicolumn{2}{|c|}{ Freshmen admitted } & \multirow{2}{*}{\multicolumn{2}{|c|}{ Transferred }} & \multirow{2}{*}{\multicolumn{2}{|c|}{ Withdrawn }} & \multirow{2}{*}{\multicolumn{2}{|c|}{ Total exit rate }} & \multirow{3}{*}{$\begin{array}{c}\begin{array}{c}\text { Retention } \\
\text { rate }\end{array} \\
81.1 \%\end{array}$} \\
\hline Year & Females & & & & & & & \\
\hline 2001 & 122 & 10 & $8.2 \%$ & 13 & $10.7 \%$ & 23 & $18.9 \%$ & \\
\hline 2002 & 109 & 13 & $11.9 \%$ & 13 & $11.9 \%$ & 26 & $23.9 \%$ & $76.1 \%$ \\
\hline 2003 & 64 & 7 & $10.9 \%$ & 15 & $23.4 \%$ & 22 & $34.4 \%$ & $65.6 \%$ \\
\hline 2004 & 66 & 6 & $9.1 \%$ & 15 & $22.7 \%$ & 21 & $31.8 \%$ & $68.2 \%$ \\
\hline 2005 & 75 & 6 & $8.0 \%$ & 8 & $10.7 \%$ & 14 & $18.7 \%$ & $81.3 \%$ \\
\hline $\begin{array}{c}01 \sim 05 \\
\text { ( Before WIE) }\end{array}$ & 436 & 42 & $9.6 \%$ & 64 & $14.6 \%$ & 106 & $24.3 \%$ & $75.7 \%$ \\
\hline 2006 & 68 & 0 & $0.0 \%$ & 11 & $16.2 \%$ & 11 & $16.2 \%$ & $83.8 \%$ \\
\hline 2007 & 70 & 3 & $4.3 \%$ & 10 & $14.3 \%$ & 13 & $18.6 \%$ & $81.4 \%$ \\
\hline 2008 & 67 & 3 & $4.5 \%$ & 8 & $11.9 \%$ & 11 & $16.4 \%$ & $83.6 \%$ \\
\hline 2009 & 78 & 7 & $9.0 \%$ & 4 & $5.1 \%$ & 11 & $14.1 \%$ & $85.9 \%$ \\
\hline 2010 & 90 & 4 & $4.4 \%$ & 3 & $3.3 \%$ & 7 & $7.8 \%$ & $92.2 \%$ \\
\hline $06 \sim 10$ & 373 & 17 & $4.5 \%$ & 36 & $9.6 \%$ & 53 & $14.2 \%$ & $85.8 \%$ \\
\hline
\end{tabular}




\section{Conclusions}

This study presents the effectiveness of a program that uses gender perspective in engineering education. The psychological correlates of career development, employment rate and retention ratio were analyzed and correlated with program participation. The major conclusions are as follows:

1. Female students have a high level of desire for employment related to their major, and high career aspiration, but the employment self-efficacy was relatively low. However, students with program participation experience scored higher in all areas.

2. For female students who were evaluated, their initiative, willingness to challenge, and confidence improved through program participation.

3. The employment rate and retention rate of female students increased significantly after the WIE program was initiated.

This result proves that the WIE program has a positive influence on female student psychological correlates of career development. This is an encouraging result that the dissemination of the WIE project can contribute to the recruiting and retention of female students in engineering.

\section{References}

1. Min, M. S. and Lee, J. H. (2005). Analysis of Educational and Occupational Experiences of Women Studying Engineering, Korean Education and Sociology Research, 15(2), 65-93

2. Kim, J. H., Jeoung, Y. K, and Oh, M. S., (2007). Educational Programs for Women Engineers to be more Industry-Competitive. Korean Industrial Technology Foundation Research Report

3. Jeoung, Y. K, Oh, M. S., and Kim, J. H, (2008) "Examination of Psychological Correlates of Women Engineering Students "J. of Engineering Education Research, 5(4), 34-45

4. Hahn, J. H. (2005). Study on personal characteristics for male-dominated career choice and employment behavior of female college students, Master's Thesis, Sungshin Women's University.

5. O'Brien, K. M. (1992). Career aspiration scale, college Park: University of Maryland. 